\title{
Kemiskinan dan kondisi pemukiman nelayan tradisional (studi di Kelurahan Kampung Nelayan Kecamatan Tungkal Ilir Kabupaten Tanjung Jabung Barat)
}

\author{
Nurhayani*; Siti Hodijah \\ Prodi Ekonomi Pembangunan Fakultas Ekonomi dan Bisnis Universitas Jambi \\ *E-mail korespondensi: nurhayani2106@yahoo..com
}

\begin{abstract}
This study aims to analyze the poverty problems of traditional fishermen at Nelayan Village Tungkal Ilir District, Tanjung Jabung Barat Regency. And analyze the condition of coastal settlements of traditional fishing communities at Nelayan Village Tungkal Ilir District, Tanjung Jabung Barat Regency. The poverty that occurs in traditional fishermen at Nelayan Village is caused by 3 (three) most influential factors. There are; 1) quality factor of human resources, 2) economic factor, and 3) institutional factor. The spread pattern of settlements of traditional fishing communities at Nelayan Village takes place naturally, spontaneously and tend to be sporadic. This fishing community settlement tends to be dense.
\end{abstract}

Keywords: Poverty, Traditional Fishermen

\begin{abstract}
Abstrak
Penelitian ini bertujuan untuk menganalisis masalah kemiskinan nelayan tradisional Kelurahan Kampung Nelayan Kecamatan Tungkal Ilir Kabupaten Tanjung Jabung Barat Menganalisi kondisi pemukiman pesisir masyarakat nelayan tradisional Kelurahan Kampung Nelayan Kecamatan Tungkal Ilir Kabupaten Tanjung Jabung Barat Kemiskinan yang terjadi pada nelayan tradisional di Kampung Nelayan disebabkan oleh 3 (tiga) faktor yang sangat berpenganih. yaitu: 1) faktor kualitas sumber daya manusia 2) Faktor ekonomi: dan 3) faktor kelembagaan. Pola penyebaran permukiman kampung nelayan ini berlangsung alamiah, spontan dan cenderung sporadik. Permukiman masyarakat nelayan ini cenderung padat.
\end{abstract}

Kata kunci: Kemiskinan, Nelayan Tradisional

\section{PENDAHULUAN}

Masyarakat pesisir sebagian besar berprofesi sebagai nelayan yang diperoleh secara turun-temurun dari nenek moyang mereka. Karakteristik masyarakat nelayan terbentuk mengikuti sifat dinamis sumberdaya yang digarapnya, sehingga untuk mendapatkan hasil tangkapan yang maksimal, nelayan harus berpindah-pindah. Selain itu, resiko usaha yang tinggi menyebabkan masyarakat nelayan hidup dalam suasana alam yang keras yang selalu diliputi ketidakpastian dalam menjalankan usahanya (Sebenan, 2007).

Masyarakat nelayan menghadapi sejumlah masalah politik, sosial dan ekonomi yang komplek. Hal ini disebabkan oleh kebijakan pembangunan yang belum bersungguh-sungguh, persoalan sosial ekonomi dan budaya yang terjadi pada masyarakat nelayan cukup kompleks, sehingga tidak mudah untuk menyelesaikan 
masalah. Masyarakat merupakan pelaku utama bagi pembangunan, maka diperlukan kualitas sumber daya manusia yang berpotensial. Titik berat pembangunan pendidikan diletakkan pada peningkatan mutu setiap jenjang pendidikan serta memperluas kesempatan belajar pada jenjang menengah.

Kabupaten Tanjung Jabung Barat merupakan satu dari dua Kabupaten di Provinsi Jambi yang memiliki wilayah laut. Hal ini menyebabkan sebagian besar masyarakat tinggal dan menepati daerah sekitar wilayah pesisir serta menggantungkan hidupnya sebagai nelayan (Ningsih, 2013). Kampung Nelayan adalah salah satu kelurahan yang terletak di kecamatan Tungkal Ilir, Kabupaten Tanjung Jabung Barat. Kampung Nelayan adalah hasil pemekaran dari kelurahan Tungkal II yang dibentuk dengan PerdaNomor 22 Tahun 2011. Kampung Nelayan mempunyai luas 1,33 $\mathrm{KM}^{2}$, memiliki 16 RT yang mata pencaharian masyarakatnya $80 \%$ sebagai nelayan.

Nelayan Tradisional umumnya memiliki permasalahan rendahnya tingkat kesejahteraan rakyat pesisir dan kualitas lingkungan. Tingkat kesejahteraan masyarakat yang cukup rendah diperlihatkan dari sebaran kawasan tertinggal yang banyak terdapat wilayah pesisir. Salah satu penyebabnya adalah minimnya prasarana dan sarana pendukung bidang kelautan dan perikanan. Sedangkan rendahnya kualitas lingkungan pada kawasan permukiman para nelayan disebabkan minimnya ketersediaan prasarana dan sarana dasar yang berdampak pada rendahnya produktivitas (WALHI, 2008).

Masalah timbul karena tidak adanya kesesuaian antara sesuatu yang diharapkan dengan kenyataan atau karena adanya keraguan tentang sesuatu keadaan. Dalam suatu penelitian harus jelas apa permasalahan yang akan diteliti. Jika permasalahan Penelitian sudah ditentukan, maka akan memudahkan peneliti untuk mengetahui penyebabnya. Masalah kemiskinan di kalangan masyarakat nelayan merupakan masalah yang sulit diselesaikan. Kampung Nelayan merupakan salah satu kawasan pesisir, sebagian besar dengan mata pencaharaian adalah sebagai nelayan tradisional daerah penangkapan nelayan tradisional. Rumusan masalahdalam penelitian ini adalah 1)Faktor - faktor apa saja yang mempengaruhi Kemiskinan nelayan tradisional Kelurahan Kampung Nelayan Kecamatan Tungkal Ilir Kabupaten Tanjung Jabung Barat? 2) Bagaimana Kondisi pemukiman Kelurahan Kampung Nelayan Kecamatan Tungkal Ilir Kabupaten Tanjung Jabung Barat?

Menurut UU No. 27 Tahun 2007 Tentang batasan wilayah pesisir, kearah daratan mencakup wilayah administrasi daratan dan kearah perairan laut sejauh 12 (dua belas) mil laut diukur dari garis pantai ke arah laut lepas dan/atau kearah perairan kepulauan wilayah pesisir merupakan wilayah yang unik karena merupakan tempat percampuran antara daratan dan lautan, hal ini berpengaruh terhadap kondisi fisik dimana pada umumnya daerah yang berada di sekitar laut memiliki kontur yang relatif datar. Adanya kondisi seperti ini sangat mendukung bagi wilayah pesisir dijadikan daerah yang potensial dalam pengembangan wilayah keseluruhan. Hal ini menunjukan garis batas nyata wilayah pesisir tidak ada. Batas wilayah pesisir hanyalah garis khayalan yang letaknya ditentukan oleh kondisi dan situasi setempat. Di daerah pesisir yang landai dengan sungai besar, garis batas ini dapat berada jauh dari garis pantai. Sebaliknya di tempat yang berpantai curam dan langsung berbatasan dengan laut dalam, wilayah pesisirnya akan sempit.

Untuk mengukur kemiskinan, menggunakan konsep kemampuan memenuhi kebutuhan dasar (basic needs approach) (BPS). Dengan pendekatan ini, kemiskinan dipandang sebagai ketidakmampuan dari sisi ekonomi untuk memenuhi kebutuhan dasar makanan dan bukan makanan yang diukur dari sisi pengeluaran. Jadi Penduduk Miskin adalah penduduk yang memiliki rata-rata pengeluaran perkapita perbulan dibawah garis kemiskinan. 
Pendapatan nelayan dari usaha penangkapan tidak menentu karena berbagai faktor seperti modal kerja, jam kerja melaut, harga ikan, dan teknologi berpengaruh positif terhadap pendapatan nelayan (Syechalad dan Hardiyanto, 2009). Jumlah anggota keluarga yang bekerja juga mempengaruhi tingkat pendapatan keluarga nelayan (Agunggunanto, 2011). Semakin meningkatnya harga ikan, belum tentu menjadi jaminan Kemiskinan Absolut

Kemiskinan absolut atau mutlak berkaitan dengan standar hidup minimum suatu masyarakat yang diwujudkan dalam bentuk garis kemiskinan (poverty line) yang sifatnya tetap tanpa dipengaruhi oleh keadaan ekonomi suatu masyarakat. Garis Kemiskinan (poverty line) adalah kemampuan seseorang atau keluarga memenuhi kebutuhan hidup standar pada suatu waktu dan lokasi tertentu untuk melangsungkan hidupnya. Pembentukan garis kemiskinan tergantung pada defenisi mengenai standar hidup minimum. Sehingga kemiskinan abosolut ini bisa diartikan dari melihat seberapa jauh perbedaan antara tingkat pendapatan seseorang dengan tingkat pendapatan yang dibutuhkan untuk memenuhi kebutuhan dasarnya. Tingkat pendapatan minimum merupakan pembatas antara keadaan miskin dengan tidak miskin.

Kelurahan Kampung Nelayan mimiliki kekayaan laut yang beraneka ragam, sumber daya alam yang dapat pulih dan sumber daya alam yang tak dapat pulih. pendapatan nelayan akan meningkat, karena kenaikan harga ikan juga dipengaruhi oleh biaya produksi serta kebutuhan nelayan yang juga meningkat. Konsumsi merupakan salah satu kegiatan ekonomi rumah tangga dalam rangka memenuhi berbagai kebutuhan barang dan jasa. Dari barangdan jasa yang dikonsumsi itulah rumah tangga akan mempunyai kualitas hidup tersendiri. Oleh karena itu, konsumsi seringkali dijadikan salah satu indikator kesejahteraan keluarga. Makin besar pengeluaran untuk konsumsi barang dan jasa, maka makin tinggi tahap kesejahteraan keluarga tersebut (Munparidi, 2010). Konsumsi yang dikeluarkan oleh rumah tangga berkaitan dengan kemiskinan.

Menurut Retnowati (2011) definisi kemiskinan adalah keadaan dimana terjadi ketidak mampuan untuk dapat memenuhi kebutuhan dasar seperti makanan, pakaian, tempat berlindung, pendidikan, dan kesehatan. Ciri-ciri demografi yang berhubungan dengan pendapatan nelayan dan kemiskinan meliputi: umur, tingkat pendidikan, pengalaman sebagai nelayan, jumlah keluarga dan anggota keluarga yang bekerja. Sedangkan sosio-ekonomi nelayan berkaitan dengan variabel/variabel pemilikan perahu, jenis perahu, nilai aset penangkapan ikan, nilai aset di luar aktivitas penangkapan ikan.Variabel sosio-budaya mencakup variabel institusi koperasi, hubungan dengan pemilik modal, dan perilaku nelayan, umur, tingkat pendidikan, pengalaman (lama sebagai nelayan), jumlah anggota keluarga dan anggota keluarga yang bekerja. Faktor sosio ekonomi mencakupi variabel pemilikan perahu, jenis perahu, pendapatan nelayan dan keluarga mereka. Faktor sosio budaya berkaitan dengan perilaku nelayan, institusi koperasi, hubungan nelayan dengan pemilik modal, yaitu pinjaman dan penjualan ikan.

\section{METODE}

Dalam penelitian ini pengumpulan data dilakukan melalui kuesioner. Pedoman wawancara dan pengamatan. Metode analisis data yang digunakan adalah metode kualitatif. Dalam penelitian ini jumlah sampel sebesar 78 Kepala Keluarga yang diambil berdasarakan simple random sampling. Penelitian ini bersifat deskriptif dengan dasar studi kasus. Menurut Faisal (2003), penelitian yang bertujuan untuk mengungkapkan suatu kenyataan sosial dengan jalan mendeskripsikan secara tepat sifat individu, keadaan, gejala, kelompok tertentu berkenaan dengan masalah unit yang diteliti dalam masyarakat. Data yang terkumpul melalui penyebaran kuisioner akan disajikan dalam 
bentuk tabel dan beberapa data yang dikumpulkan melalui wawancara diringkas dan kemudian data diatampilkan untuk dapat dipahami keadaan yang sebenarnya. Data yang di hasilkan berdasarkan observasi dianalisis sesuai dengan tujuan penelitian.

Penelitian ini menggunakan jenis data primer. Data primer diperoleh langsung dari para nelayan yang ada di Kampung Nelayan dengan cara pengamatan dan hasil wawancara. Disamping menggunakan data primer penelitian ini juga menggunakan data sekunder yang diperoleh dari instansi terkait.

Untuk mengetahui faktor-faktor penyebab kemiskinan nelayan tradisional di Kampung Nelayan, maka beberapa indikator diberikan ukuran atau kategori secara kualitatif.

1. Faktor sumberdaya manusia
a) Tingkat pendidikan
b) Pekerjaan sampingan
c) Lama usaha

Jika ketiga unsur terpenuhi, dikatagorikan sangat berpengaruh, jika dua unsur terpenuhi dikatagorikan berpengaruh dan jika satu unsur yang terpenuhi dikatagorikan tidak berpengaruh

2. Faktor ekonomi
a) Kepemilikan modal
b) Kepemilikan tanah
c) Teknologi yang digunakan

Jika ketiga unsur terpenuhi, dikatagorikan sangat berpengaruh, jika dua unsur terpenuhi dikatagorikan berpengaruh dan jika satu unsur yang terpenuhi dikatagorikan tidak berpengaruh

3. Kelembagaan
a) Peranan koperasi
b) Peranan lembaga perkreditan
c) Peranan pemasaran

Jika ketiga unsur terpenuhi, dikatagorikan sangat berpengaruh, jika dua unsur terpenuhi dikatagorikan berpengaruh dan jika satu unsur yang terpenuhi dikatagorikan tidak berpengaruh.

\section{HASIL DAN PEMBAHASAN}

\section{Karakteristik responden}

Responden dalam penelitian ini adalah masyarakat Kampung Nelayan, selanjutnya untuk memberikan gambaran yang jelas tentang responden, akan dijelaskan beberapa karakteristik responden diantaranya adalah umur responden, tingkat pendidikan responden dan jumlah tanggungan.

\section{Umur responden}

Diketahui bahwa usia responden di Kampung Nelayan sebagian besar pada usia produktif. Jumlah umur responden terbesar pada umur 28-34 tahun sebanyak 25,64\% dan pada umur 49-55 tahun sebanyak $24,36 \%$. Ada 7,69 \% responden yang tergolong kelompok usia tidak produktif namun masih tetap bekerja sebagai nelayan. Keberadaan responden yang berada di usia produktif menunjukkan bahwa responden mempunyai kecenderungan kemampuan untuk mempelajari, memahami, menerima dan mengadopsi inovasi baru dan di usia yang relatif muda akan lebih cepat mengambil keputusan teknologi yang akan diadopsi. Hal ini juga menjadi petunjuk bahwa bahwa aktivitas nelayan pada umumnya memerlukan stamina dan tenaga besar dalam menjalankan aktifitasnya. 


\section{Tingkat pendidikan responden}

Distribusi responden berdasarkan tingkat pendidikan bertujuan untuk mengetahui salah satu aspek dari kualitas sember daya manusia Di Kampung Nelayan. Selain umur responden, tingkat pendidikan seseorang juga memiliki pengaruh dalam pengelolaan usaha. Pendidikan terkait dengan tingkat pengetahuan, produktivitas serta keterampilan usaha perikanan dan akhirnya akan mempengaruhi responden dalam pengambilan keputusan. Diketahui bahwa responden sebagian besar memiliki kualifikasi pendidikan rendah tamat SD yaitu sebesar $65,38 \%$ dan yang tamat SMA hanya $12,82 \%$. Rendahnya tingkat pendidikan nelayan disebabkan oleh rendahnya pendapatan orang tua sehingga tidak mampu membiayai anaknya ke jenjang pendidikan yang lebih tinggi. Hal ini mengakibatkan anak nelayan harus membantu dalam mencari nafkah sehingga pekerjaan sebagai nelayan bersifat turun temurun.

\section{Jumlah tanggungan keluarga}

Jumlah keluarga adalah suatu faktor penting yang mempengaruhi kemiskinan rumah tangga). Faktor ini dapat mempengaruhi kemiskinan dalam dua arah. Pertama, mungkin secara langsung mempengaruhi kemiskinan, selama pendapatan rumah tangga tetap, meningkatnya jumlah keluarga akan menekan tingkatan konsumsi riil anggota keluarga. Kedua, sekalipun tiap anggota rumah tangga mempunyai pendapatan, pendapatan per kapita dapat menurun dengan bertambahnya jumlah keluarga berkenaan dengan diminishing marginal.

Karakteristik selanjutnya adalah jumlah anggota rumah tangga yang dikelompokkan menjadi 2 kategori. Jumlah anggota rumah tangga dapat mempengaruhi terhadap besarnya tanggungan keluarga. Jumlah tanggungan keluarga ialah banyaknya anggota keluarga dalam suatu- rumah yang menjadi tanggungan kepala keluaraga.. Beban tanggungan kepala keluarga responden penelitian yang memiliki beban tanggungan $>3$ terdapat 36 orang $(46,15 \%)$ sedangkan yang memiliki jumlah tanggungan $<3$ terdapat 42 orang $(53,85)$. Hal ini menggambarkan bahwa, pada umumnya nelayan tradisional mempunyai jumlah tanggungan keluarga yang cukup besar. Karena besarya jumlah tanggungan membuat besar pula pengeluaran yang harus dikeluarkan oleh nelayan tradisional.

\section{Faktor - faktor penyebab kemiskinan nelayan tradisional di Kelurahan Kampung Nelayan Kecamatan Tungkal Ilir Kabupaten Tanjung Jabung Barat}

Untuk mengetahui faktor-faktor penyebab kemiskinan nelayan tradisional di kampung Nelayan, maka beberapa indikator diberikan ukuran atau kategori secara kualitatif. Faktor SDM, Faktor ekonomi dan faktor Kelembagaan.

\section{Faktor sumber daya manusia}

Kemiskinan muncul merupakan salah satu akibat dari adanya perbedaan dalam kualitas sumber daya manusia. Jika kualitas sumber daya manusia rendah maka akan menyebabkan rendahnya produktivitas, dan akhirnya menyebabkan rendahnya pendapatan. Sebaliknya jika kualitas sumberdaya manusianya tinggi maka produktivitasnya akan tinggi dan akan meningkatnya pendapatan. Terkait dengan hal tersebut, faktor sumberdaya manusia yang dianalisis dalam hal ini adalah tingkat pendidikan, pekerjaan sampingan dan lama usaha.

\section{Tingkat pendidikan}

Tingkat pendidikan sebagai salahsatu indikator dari kulaitas sumber daya manusia. Diketahui bahwa responden sebagian besar memiliki kualifikasi pendidikan rendah tamat SD yaitu sebesar 65,38 persen dan yang tamat SMP sebesar 21,8 persen yang tamat SMA hanya 12,82 persen. Rendahnya tingkat pendidikan nelayan 
disebabkan oleh rendahnya pendapatan orang tua sehingga tidak mampu membiayai anaknya ke jenjang pendidikan yang lebih tinggi. Rendahnya tingkat pendidikan untuk bekal menjadi nelayan memang tidak penting, karena pekerjaan melaut hanya mengandalkan otot dan pengalaman bukan pemikiran, sehingga setinggi apapun pendidikan tidak mempengaruhi kecakapan mereka melaut. Jika mereka akan bekerja sebagai karyawan atau pekerjaan selain melaut maka merak akan mengalami kesulitan.

\section{Pekerjaan sampingan}

Dalam memenuhi kebutuahn sehari-hari diperlukan pekerjaan sampingan bagi nelayan, karena tidak setiap hari dapat melaut, salah satunya adalah faktor cuaca dan apalagi hasil tangkapan tidak dapat dihandalkan sedangkan kebutuhan sehari-hari harus dipenuhi. Karena pendidikan rendah maka akan sulit bagi meraka untuk mendapatkan pekerjaan sampingan yang semustinya, kecuali menjadi buruh kasar. Diketahui bahwa dari 78 responden terdapat 44,87 persen responden tidak memiliki perkerjaan sampingan, dan 11,53 persen pekerja di perkebunan, 10,25 persen kerja sampingan sebagai tenaga kerja bangunan, 10,25 persen bekerja di transportasi dan pergudangan. Memiliki pekerjaan sampingan sebagai petani palawija (padi). bukanlah suatu pekerjaan yang menjanjikan keuntungan besar. malah tidak jarang dan mereka sering mengalami kerugian Karena biaya produksi yang lumayan tinggi.

Sedangkan bagi mereka yang tidak rnernpunyai pekerjaan sampingan, menurut pengamatan ternyata kegiatan yang biasa dilakukan setelah dan ketika tidak melaut adalah duduk dan ngobrol di warung-warung kopi. Di sana mereka bercerita mulai dan masalah pekerjaan sampai dengan hal-hal yang sangat pribadi,

Kebiasaan tersebut sudah menjadi sebuah kebiasaan bagi nelayan. bukan hanya nelayan tradisional di Kampung Nelayan, bahkan hampir semua nelayan melakukan kebiasaan yang sama.

\section{$\underline{\text { Lama usaha }}$}

Lama usaha merupakan lamanya nelayan berkekerja. Lamanya suatu usaha dapat menimbulkan pengalaman berusaha, dimana pengalaman dapat mempengaruhi pengamatan (kemampuan profesionalnya/keahliannya. Pengaruh pengalaman berusaha terhadap tingkat pendapatan dan akan mempengaruhi kemampuan profesionalnya. Semakin lama menekuni sebagai nelayan akan makin meningkatkan pengetahuan tentang sesuatunya. Ketrampilan dan kecakapan melaut makin bertambah. Berdasarkan survey yang dilakukan terdapat 25,64 persen yang melaut sudah 25-30 tahun, 24,35 persen yang sudah melaut 30-35 tahun, bahkan ada yang lebih dari 35 tahun menjali pekerjaan sebagai pelaut. Namun dalam hal melaut, menurut para nelayan tidak hal yang dominan mempengaruhi besaran hasil yang diperoleh, karena melaut sangat tergantng dengan cuaca dan musim.

\section{Faktor ekonomi}

Faktor ekonomi merupakan salah satu faktor yang dianalisis pada masalah kemiskinan nelayan tradisional di kampung nelayan yang mencakup kepemilikan modal, kepemilikan tanah dan teknologi yang digunakan.

\section{Kepemilikan modal}

Kaitannya dengan modal, pada umurnnya nelayan tradisional tidak memiliki modal untuk pengembangan usaha. sehingga mereka tidak dapat melakukan peningkatan input produksi baik dan segi jumlah maupun kualitasnya akumulasi modal). Tidak dapat melakukan peningkatan input produksi rnengakibakan rendahnya produtivitas. Rendahnya produktivitas mengakibatkan rendahnya pendapatan yang diterirna. Dari 78 responden terdapat 89,74 persen tidak memiliki modal yang dan 10,25 persen memiliki modal yang secukupnya untuk pengembangan usaha. Akibatnya nelayan tidak dapat melakukan peningkatan produksi. Sedangkan rendahnya produksi 
sangat berpengaruh kepada jumlah pendapatan yang diterima. Artinya bila produksi rendah. maka akan rendah pula pendapatan yang diterima oleh nelayan. Sejalan dengan itu sebagaimana dijelaskan pada lingkaran kemiskinan bahwa rendahnya pendapatan yang diterima berakibat kepada rendahnya tabungan. Selanjutnya rendahnya tabungan berimplikasi kepada rendahnya investasi. Sedangkan rendahnya investasi mengakibatkan kembali terjadi kekurangan modal. Sehubungan dengan itu kepemilikan tabungan merupakan salah satu kunci bagi nelayan dalam kepernilikan modal.

\section{Kepemilikan tanah}

Tanah adalah aset yang dapat digunakan orang untuk tempat kegiatan usaha. seperti industry, perdagangan dan pertanian. Dengan kata lain tanah merupakan aset produksi untuk rnenghasilkan barang dan jasa yang selanjutnya akan menghasilkan pendapatan. Artinya mereka yang memiliki tanah dan rnengelolanya dengan baik akan menghasilkan pendapaan yang lebih tinggi dibandingkan dengan mereka yang tidak memiliki tanah. Berdasarkan penelitian yang dilakukan terhadap 78 responden tentang kepemilikan tanah bagi nelayan tradisional. diketahui bahwa 87,17 persen responden tidak memiliki tanah dan 12,82 persen memiliki tanah yang dapat digarap untuk usaha pertanian sebagai usaha sampingan.

\section{Teknologi yang digunakan}

Salah satu ciri dan usaha nelayan tradisional adalah teknologi penangkapan yang bersifat sederhana dengan ukuran perahu yang kecil. Daya jelajah terbatas, daya muat perahu sedikit. Secara urnurn perahu penangkapan ikan yang digunakan oleh nelayan tradisional mernpunyai ciri: berbahan kayu. ada yang menggunakan motor tempel. juga ada yang menggunakan layar sebagai pengganti motor tempel. panjang antara 5-8 meter. lebar 1-2 meter. tnggi 0.5 meter. Awak perahu 1-3 orang. kecepatan jelajah terbatas. hanya mampu beroperasi di perairan sekitamya. Berdasarkan pengamatan. perahu yang digunakan oleh nelayan tradisional di Kampung Nelayan adalah Perahu yang menggunakan mesin tempel dengan kapasitas mesin 1,5 PK. Badan perahu terbuat dan kayu. Alat tangkap yang digunakan adalah jaring dan pancing. Umumnya mesin-mesin yang digunakan pada perahu-perahu tersebut kondisinya sudah lama yang ditunjukkan oleh banyaknya karatan.

Berdasarkan uraian diatas dapat disimpulkan bahwa faktor ekonomi dapat dikatagorikan sebagai faktor yang sangat berpengaruh terhadap kemiskinan nelayan tradisional di Kampung Nelayan, karena dan tiga indikator yang diteliti menunjukkan faktor ekonomi sebagai faktor penyebab kerniskinan nelayan tradisional di Kampung Nelayan.

\section{Faktor kelembagaan}

Studi empiris Pusat Penelitian Sosial Ekonomi Departemen Pertanian (1995) dalam Yenny (2000: 18) menyimpulkan bahwa ada enam faktor penyebab kemiskinan masyarakat pedesaan di Indonesia, salah satunya adalah kurang berperannya lembaga yang ada. Faktor kelembagaan yang dianalisis dalam hal ini adalah peranan koperasi, peranan lembag perkreditan dan peranan pemasaran.

\section{Peranan koperasi}

Keterbatasan modal merupakan kesulitan mendasar yang dialami nelayan tradisional untuk melakukan pengembangan usaha karena sifat bisnis perikanan yang musiman. penghasilan yang tidak menentu sehingga beresiko tinggi sering menjadi alasan keengganan bank untuk memberikan bantuan modal usaha bagï nelayan. Sifat bisnis perikanan beresiko ini dan disertai dengan status nelayan yang umumnya rendah dan tidak mampu secara ekonorni membuat mereka kesulitan dalarn mernenuhi syaratsyarat yang diberlakukan oleh perbankan. Sebenarnya upaya ini telah dilakukan oleh nelayan tradisional dengan mendirikan sebuah koperasi nelayan namun usaha ini tidak 
berjalan dengan mustinya, karena banyak kendala yagn dihadapi terutama dalam hal cicilan yang sering macet dan tidak dapat meminjma dalam jumlah besar karena tidak adanya jaminan.

\section{Peranan lembaga perkreditan}

Untuk dapat memberikan kredit pihak yang bersangkutan tentu akan meminta jaminan, hal ini yang menyulitkan pihak nelayan, karena meraka tidak memiliki jaminan yang dapat dianggunkan ke pihak bank. Berdasarkan hasil wawancara masyarakat ingin sekali mengajukan kredit namun banyak syarat-syarat yang tidak dapat mereka penuhi, selain usaha yang tidak pasti dan klasifikasi usaha yang tidak lengkap membuat pihak nelayan tidak mendapatkan pinjaman. Dan ada juga nelayan yang enggan ataun malu ke bank untuk mengajukan pinjaman.

\section{Peranan pemasaran}

Pasar adalah faktor penarik dan bisa menjadi salah satu kendala utama bila pasar tidak berkembang. Untuk mengembangkan pasar bagi produk-produk yang dihasilkan nelayan maka upaya yang dilakukan adalah mendekatkan masyarakat dengan pasar seperti eksportir komoditas perikanan. Keuntungan dan hubungan seperti ini yaitu nelayan mendapat jaminan pasar dan barga, pembinaan terhadap nelayan terutama dalam hal kualitas barang bisa dilaksanakan, serta seringkali nelayan mendapat juga bantuan modal bagi pengembangan usaha yang dihasilkan Struktur pasar yang tidak menguntungkan nelayan ini disebabkan karena informasi yang kurang mengenai harga. Sehingga harga lebih sering dirnonopoli oleh toke-toke ikan. di mana mereka membeli dengan harga murah dan menjualnya kepada eksportir dengan harga yang berlipat ganda Begen dalam Mussawir (2009). Tidak banyak yang dapat dilakukan dalam hal pemasaran karena selain tangkapan yang tidak pasti namun juga karena jumlahnya tidak banyak. Ada koperasi namun sejauh ini tidak banyak membantu nelayan dalam hal pemasaran.

\section{Kondisi pemukiman nelayan tradisional di Kelurahan Kampung Nelayan Kecamatan Tungkal Ilir Kabupaten Tanjung Jabung Barat}

Pola penyebaran permukiman kampung nelayan ini berlangsung alamiah, spontan dan cenderung sporadik. Permukiman masyarakat nelayan ini cenderung padat. Diperkirakan sekitar sebagian besar dari seluruh perumahan kampung nelayan ini, kondisi rumah tempat tinggalnya belum mendapat perawatan dan pemeliharaan dengan baik. Dilihat dari kondisi strukturkonstruksi bangunan, perumahan kampung nelayan ini cenderung menggunakan struktur-konstruksi bangunan sederhana, dengan bentuk bangunan trandisional, dengan sebagian besar memiliki bentuk atap pelana.

Melihat jenis prasarana dasar pendukung permukiman kampung nelayan, pada umumnya prasarana yang ada dinilai cukup memadai. Kondisi jalan-jalan lingkungan di sekitar permukiman nelayan terlihat pada beberapa tempat atau bagian masih kurang baik perawatannya. Demikian pula dengan kondisi saluran drainase pembuangan air hujan, pada beberapa lokasi masih sangat minim. sebagian besar dari warga permukiman ini menggunakan air sumur untuk pemenuhan kebutuhan air bersih. Upaya penataan pada skala rumah tinggal para nelayan yang ada bertujuan untuk meningkatkan kualitas kenyamanan dan meningkatkan mutu bangunan yang lebih sehat. Pertama, pada tingkat atau skala lingkungan permukiman kampung nelayan, kondisi fisik kampung nelayan perlu diupayakan untuk ditingkatkan penataan lingkungan fisikekologisnya. 


\section{KESIMPULAN DAN SARAN}

\section{Kesimpulan}

Kemiskinan nelayan tradisional di Kampung Nelayan disebabkan oleh 3 (tiga) faktor utama yaitu: 1) faktor kualitas sumber daya manusia 2) Faktor ekonorni: dan 3) faktor kelernbagaan. Rendahnya kualitas sumber daya manusia ditandai dengan rendahnya tingkat pendidikan. tidak dimilikinya ketrampilan alternatif dan kurangnya pekerjaan alternatif (sampingan) oleh nelayan. Lemahnya ekonomi nelayan ditandai dengan tidak mimilikinya aset-aset produksi seperti modal. tanah dan teknologi yang modernoleh nelayan. Sedangkan lemahnya peranan keleinbagaan ditandai dengan masih lemahnya peranan lembaga yang ada dalarn meningkatkan ekonomi nelayan.

Pola penyebaran permukiman kampung nelayan ini berlangsung alamiah, spontan dan cenderung sporadik. Permukiman masyarakat nelayan ini cenderung padat. Dilihat dari kondisi struktur konstruksi bangunan, perumahan kampung nelayan ini cenderung menggunakan struktur-konstruksi bangunan sederhana, dengan bentuk bangunan trandisional, dengan sebagian besar memiliki bentuk atap pelana.

\section{Saran}

Dalam rangka mengatasi permasalahan kemiskinan yang terjadi pada nelayan tradisional di Kampung Nelayan maka perlu pemberian pelatihan kepada keluarga nelayan agar dapat membantu keperluan keluarga disaat hasil tangkapan tidak memadai. Kemudian, sebagai langkah awal yang hal dilakukan oleh pemerintah dalarn memberikan keterjangkauan nelayan tradisional dalam mengakses sumberdaya yang tersedia kepada nelayan perlu diberikannya hal-hal yang bersifat inovatif yakni memberikan penyuluhan. pendidikan dan pelatihan ketrampilan. Di mana upaya-upaya ini tidak hanya diberikan kepada nelayan saja. tetapi juga dilakukan terhadap keluarga nelayan (istri dan anak). karena mereka merupakan potensi yang dapat menunjang pendapatan keluarga. Selanjutnya, pemerintah dapat membantu nelayan melalui lembaga keuangan non bank agar nelayan mempermudah nelayan dalam mengajuan modal usaha.

\section{DAFTAR PUSTAKA}

Agunggunanto, E.Y. (2011). Analisis Kemiskinan dan Pendapatan Keluarga Nelayan Kasus di Kecamatan Wedung Kabupaten Demak Jawa Tengah Indonesia. Jurnal Dinamika Ekonomi Pembangunan, Volume 1(1), 50-58.

Delis.A, Candra.M, Etik.U. (2015)Pengaruh FDI terhadap Kemiskinan dan Pengangguran di Indonesia 1993-2013, Jurnal Paradigma Ekonomika. 10(1), 231-245

Faisal. S. (2003). Format-Format Penelitian. Rineka Cipta: Jakarta

Alfarabi, M.A., Hidayat, M.S., Rahmadi, S. (2014). Perubahan Struktur Ekonomi dan Dampaknya Terhadap Kemiskinan di Provinsi Jambi. Jurnal Perspektif Pembiayaan dan Pembangunan Daerah, 1(3), 171-178

Munparidi. (2010).Pengaruh Pendapatan dan Ukuran keluarga Terhadapa pola konsumsi Studi Kasus Desa Ulak Kerbau Lama kecamatan Tanjung Raja Kabupaten Ogan Ilir. Jurnal Ilmiah, 2(3), 6-7

Mustika, C., Amril. (2015).Analisis Pengaruh Ekspor ke Jepang Terhadap Pertumbuhan Ekonomi dan Jumlah Pengangguran di Indonesia Periode 1993 sampai 2013.Jurnal Paradigma Ekonomika,10 (1); 246-260

Ningsih, M, dkk. (2013). Faktor-faktor Yang Mempengaruhi Pola Konsumsi Pangan dan Gizi Rumah Tangga Nelayan Kecamatan Tungkal Ilir Kabupaten Tanjung Jabung Barat. Jurnal Sosio Ekonomika Bisnis, 15(1), 48-56. 
Retnowati,E. (2011). Nelayan Indonesia Dalam Pusaran Kemiskinan Struktural Perspektif Sosial, Ekonomi dan Hukum. Jurnal Perspektif, 16(3),149-159.

Sebenan, R.D. (2007). Strategi Pemberdayaan Rumahtangga Nelayan Di Desa Gangga II Kecamatan Likupang Barat Kabupaten Minahasa Utara. Skripsi. Fakultas Perikanan dan llmu Kelautan, Universitas Sam Ratulangi: Manado.

Syechalad, M. N dan R Hardiyanto. (2009). Analisis Faktor-Faktor yang Mempengaruhi Pendapatan Nelayan di Kota Banda Aceh. Jurnal Ekonomi dan Bisnis,8(2), 106-120.

Wasak, M. (2012).Keadaan Sosial-Ekonomi Masyarakat Nelayan Di Desa Kinabuhutan Kecamatan Likupang Barat. Kabupaten Minahasa Utara, Sulawesi Utara. Pacific Journal. 1 (7), 1339-1342.

Wastuti, I,T. (2014). Strategi Arahan Pengembangan Pemukiman Nelayan Berbasis Ekowisata Di Kecamatan Pualau Sembilan Kabupaten Sinjai. Skripsi. UIN Alauddin Makasar: Makasar 